\title{
Dose-dependent vascular response following delivery of sirolimus via fast releasing, biodegradable polymer stent matrix: an experimental study in the porcine coronary model of restenosis
}

\author{
Piotr P. Buszman ${ }^{1}$, Bartłomiej Orlik ${ }^{1}$, Jacek Pająk ${ }^{2}$, Michał Jelonek ${ }^{1}$, Agata Krauze ${ }^{1}$, Adam Janas ${ }^{1}$, \\ Jacek Legutko³, Wojciech Wojakowski², Paweł E. Buszman'1, Krzysztof Milewski ${ }^{1}$ \\ ${ }^{1}$ Centre for Cardiovascular Research and Development, American Heart of Poland SA, Katowice, Poland \\ ${ }^{2}$ Medical University of Silesia, Katowice, Poland \\ ${ }^{3}$ Independent Labolatory of the Haemodynamics and Angiography Unit, Jagiellonian University Medical College, \\ University Hospital, Krakow, Poland
}

\begin{abstract}
A bstract
Background: Fast releasing, rapamycin-eluting stents, although safe, showed inferior results with regard to inhibition of restenosis. Aim: Therefore, we report vascular effects of a novel, biodegradable polymer stent matrix with elevated sirolimus dose and fast release kinetics (ed-frSES, Alex, Balton) in the porcine coronary in-stent restenosis model.

Methods: A total of 19 stents were implanted with 120\% overstretch in the coronary arteries of seven domestic pigs: seven ed-frSES with $1.3 \mu \mathrm{g} / \mathrm{mm}^{2}$ of sirolimus, eight frSES with $1 \mu \mathrm{g} / \mathrm{mm}^{2}$ of sirolimus, and eight bare metal stents (BMS). For the following 28 days, coronary angiography was performed, animals were sacrificed, and the stented segments harvested for histopathological evaluation.

Results: In angiography at 28 days the late lumen loss was lowest in the elevated dose sirolimus eluting stent (SES) (ed-frSES: $0.20 \pm 0.2$ vs. frSES: $0.80 \pm 0.5$ vs. BMS: $0.96 \pm 0.5 \mathrm{~mm}, \mathrm{p}<0.01$ ). This was confirmed in the morphometric evaluation in histopathology as represented by a significant and dose-dependent decrease in the percentage area of stenosis (ed-frSES: $22.4 \pm 12.7 \%$ vs. frSES: $35 \pm 10.7 \%$ vs. BMS: $47.5 \pm 12.5 \%, p<0.01)$. There was no peri-strut inflammation in any of the groups. However, the endothelialisation score was numerically not meaningfully decreased in ed-frSES (ed-frSES: 2.93 vs. frSES: 3. vs. BMS: $3, p=0.05$ ). Signs of fibrin were also noted in ed-frSES (ed-frSES: 0.4 vs. frSES: 0 vs. BMS: $0, p=0.05$ ).

Conclusions: Sirolimus dose-dependent vascular response was reported. The elevated dose, fast releasing SES shows satisfactory vascular healing, similar to regular dose, fast release SES, with improved efficacy in restenosis inhibition.
\end{abstract}

Key words: sirolimus eluting stent, fast release, biodegradable polymer, porcine coronary model

Kardiol Pol 2015; 73, 10: 916-923

\section{INTRODUCTION}

The balance between vascular healing process and sustained efficacy following percutaneous coronary intervention has been a challenge for nearly two decades. First-generation drug eluting stents (DES), although efficacious in restenosis inhibition when compared to bare metal stents (BMS), caused risk of late stent thrombosis due to increased inflammation, excessive fibrin deposition, and, as a consequence, impaired neointimal and endothelial coverage [1, 2]. Second-generation DES, with the utilisation of novel anti-proliferative and inflammatory rapamycin analogues along with biocompatible or biodegradable polymers, improved significantly the clinical 
outcomes when compared to first-generation DES [3-6]. Additionally, it has been shown that the optimisation of drug release kinetics may influence the vascular response and efficacy. Early generation zotarolimus eluting stent (ZES), with fast release kinetics provided superior safety, with very low risk of stent thrombosis; however, the efficacy in restenosis inhibition was inferior when compared to slow-release ZES [7]. In our recent experiments we tested the pharmacokinetics of a fast-release, regular dose $\left(1 \mu \mathrm{g} / \mathrm{mm}^{2}\right)$ sirolimus and biodegradable polymer cobalt chromium stent (FR-SES), which has shown $95 \%$ of drug elution within 90 days in an in-vivo setting and complete healing at 30 days [8]; however, the efficacy was limited, similarly to previously cited reports on ZES. In the current study we test the hypothesis that sirolimus dose increase, as well as release kinetics, may influence the vascular healing response. Therefore, the dose of sirolimus on an identical biodegradable-polymer stent matrix was elevated by $30 \%$ and vascular response evaluated in the coronary in-stent restenosis model of a swine.

\section{METHODS \\ Device description}

All stents used in this study utilised the L605 cobalt chromium alloy platform with a strut thickness of $70 \mu \mathrm{m}$ and closed cell design, which served as a bare metal control (Coflexus, Balton). Sirolimus eluting stents (SES) are covered with a fully biodegradable multilayer structure containing a copolymer of poly-lactic and glycolic acid and sirolimus. The total mass of the polymer on a $3.0 \times 15 \mathrm{~mm}$ stent does not exceed $360 \mu \mathrm{g}$. Experimental studies in the porcine in-stent restenosis model at eight weeks showed nearly full polymer biodegradation and 95\% drug release of initial drug load (Fig. 1) [8]. The studied, elevated dose SES (ed-frSES, Alex, Batlon, Poland) employs sirolimus at $1.3 \mu \mathrm{g} / \mathrm{mm}^{2}$, whereas the reference stent was at a regular dose of $1 \mu \mathrm{g} / \mathrm{mm}^{2}$ (frSES, regular dose, fast releasing sirolimus eluting stent). All stents were $3.0 \mathrm{~mm}$ and $3.5 \mathrm{~mm}$ in diameter and $15 \mathrm{~mm}$ in length.

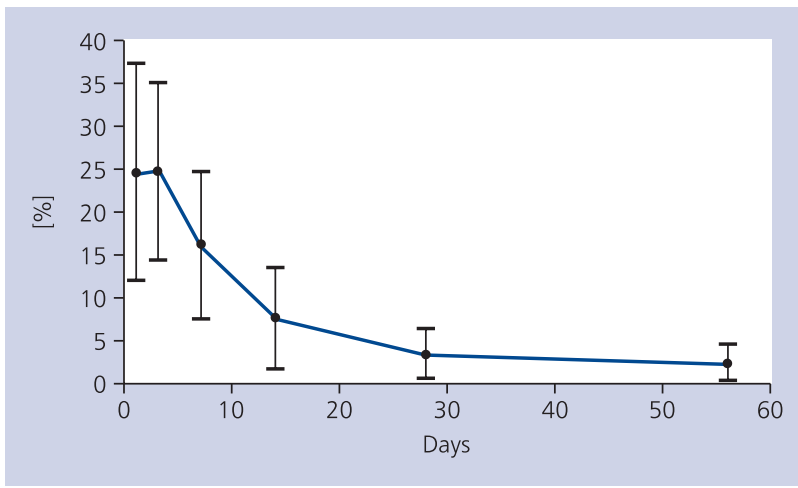

Figure 1. In vivo sirolimus tissue retention expressed as percentage of drug load on a stent depicting fast-release profile

\section{Study design}

A study flow chart is presented in Figure 2. A total of seven domestic swine of both genders were included. All animals ranged from five to seven months of age with an average weight of around $45 \mathrm{~kg}$ at the time of enrolment. Middle arterial segments without side branches of all three coronary arteries (RCA, LAD, LCX) were screened. After live quantitative coronary analysis (QCA) evaluation of 21 segments 19 segments were eligible to ensure $120 \%$ overstretch for stent implantation and inclusion. Following randomisation of vessel segments in a 2:2:1 fashion, a total of eight elevated dose, fast-release sirolimus eluting stent (ed-frSES; study group), seven frSES (reference group), and four BMS controls were implanted with a suitable pressure required for anticipated overstretch diameter. Additional inflations were performed based upon the target site diameter. The animals were followed up for 28 days. Subsequently, control coronary angiography was performed and the swine were sacrificed. All arterial segments were dissected and harvested for pathological and histomorphometric analysis. All interventions and analyses were blinded to operators and investigators.

\section{Experimental procedures}

The study protocol was approved by the Local Ethics Committee for animal research. All animals received a standard of care outlined in the study protocol and in accordance with the act of animal welfare and the "Principles of Care of Laboratory Animals" [9].

Three days prior to the procedure dual antiplatelet therapy consisting of $75 \mathrm{mg}$ of clopidogrel and aspirin per day was initiated and continued until the termination. All pigs were fasted overnight before stent implant procedure. Animals were pre-medicated with atropine $(0.5 \mathrm{mg})$ and subsequently sedated with intramuscular ketamine hydrochloride (20 mg/ $\mathrm{kg}$ ) and xylazine (2 mg/ $/ \mathrm{kg})$, intubated, and anesthetised with an intravenous propofol bolus (20-40 mg) followed by a continuous infusion $(2-4 \mathrm{mg} / \mathrm{kg} / \mathrm{h})$. Electrocardiogram and blood pressure were continuously monitored. A vascular sheath $(6 \mathrm{~F})$ was placed in the right or left femoral artery utilising the Seldinger technique. Anticoagulation with heparin was achieved (3,000-10,000 U) to maintain a coagulation time $\geq 250$ s. Following coronary angiography all coronary vessels were sized for proper stent implantation after live QCA analysis.

All pigs were anaesthetised and prepared in the same fashion as described above at 28 days following stent implantation, to perform control coronary angiography, and subsequently humanely sacrificed with pentobarbital overdose.

\section{Quantitative coronary analysis}

Coronary arteries angiographies were obtained using a Siemens Coroskop Millenium Edition angiographic unit. A Judkins Right, 6 French guiding catheter was utilised to obtain coro- 


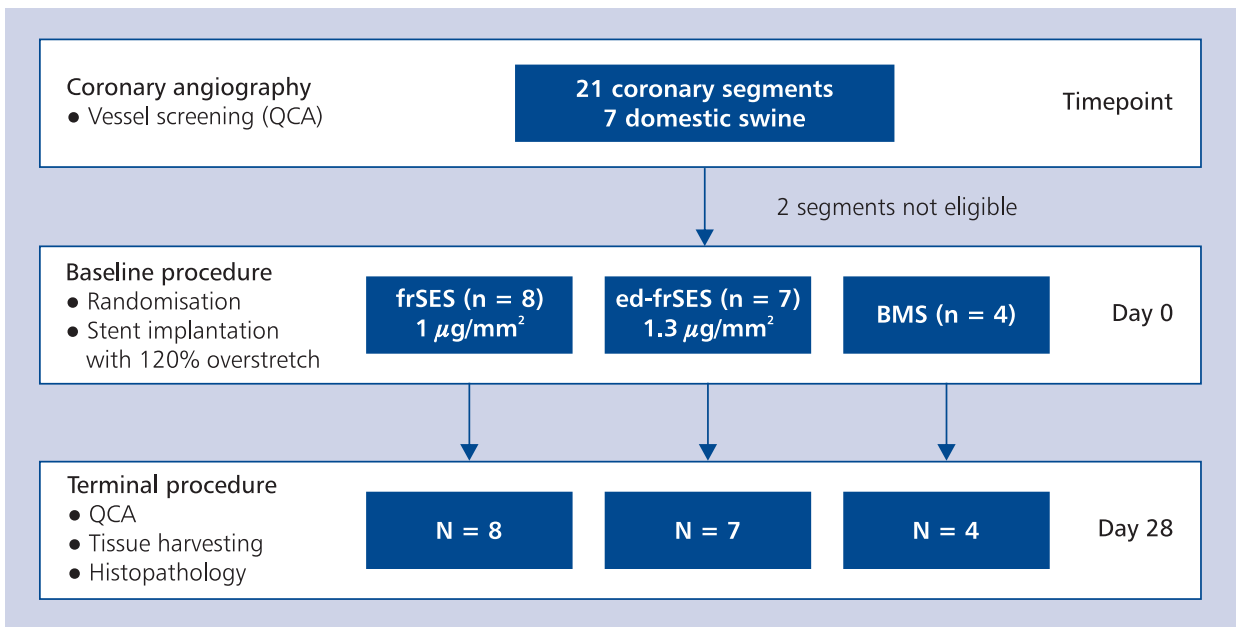

Figure 2. Study flowchart; BMS - bare metal stent; ed-frSES - elevated dose, fast-release sirolimus eluting stent; frSES — regular dose, fast-release sirolimus eluting stent; QCA — quantitative coronary analysis

nary angiography and stent implantation. QCA analysis was performed in a blinded fashion using QAngio XA Software version 7.1.14.0 (Medis Medical Imaging Systems) from two contralateral projections. The baseline and 28-day follow-up reference vessel diameters (RVD) were taken from the proximal and distal portion of the treated segments using the guiding catheter as a standard for measurement. The balloon-to-artery ratio was calculated. The percentage diameter stenosis (\%DS) at follow-up was calculated as: [1-(MLD/RVD)] × 100\%, where MLD is the minimal lumen diameter.

\section{Histological analysis}

Following vessel harvesting, stented segments were immersed in normal buffered formalin $10 \%$. For light microscopy all treated vessels were embedded in methyl methacrylate, and then 40-50 microns sections from the proximal, mid, and distal portion of each stented segment were obtained. These sections were stained with haematoxylin and eosin (H\&E). The cross-sectional areas (external elastic lamina [EEL], internal elastic lamina [IEL] and lumen area) of each section were measured. Neointimal thickness was measured as the distance from the inner surface of the stent struts to the luminal border. The following measures were used to calculate vessel layer areas: Media $=$ EEL - IEL; Neointima $=$ IEL - lumen area; \% area stenosis $=[1-($ lumen area $/$ IEL area $)] \times 100$. All sections were evaluated using semi-quantitative scoring criteria. To evaluate the amount of injury, criteria defined by Schwartz et al. [10] were used: $0=$ IEL intact, $1=$ IEL lacerated, $2=$ media lacerated, and $3=$ EEL lacerated. To evaluate the extent of peri-strut inflammatory reaction, the following grading system by Kornowski et al. [11] was used: $0=$ minimal inflammatory response around strut, $1=$ few inflammatory cells around strut, $2=$ mild to moderate inflammation, can extend into but do not efface surrounding tissue, and $3=$ dense and thick peri-strut aggregate of inflammatory cells, effacing surrounding tissue. Each strut in the section was scored and the mean inflammation and injury score for each section was calculated and reported. The adventitial inflammation score is based on the following criteria: $1=$ mild, $2=$ moderate, and $3=$ heavy peripheral inflammatory infiltration. The endothelialisation score was described as the percentage of endothelial coverage of the arterial circumference: $0=<25 \%, 1=25-75 \%$, $2=76-95 \%$, and $3=$ complete. The fibrin deposition was assessed as: 0 - none to focal, 1 - mild involving $<10 \%$ of artery circumference, 2 - moderate involving of 10-25\% artery circumference, and 3 - heavy, involving $>25 \%$ of artery circumference.

\section{Statistical analysis}

Normally distributed parametric data are expressed as average and standard deviation, and as median and interquartile range in cases of skewed distribution. When equal variance and normality were observed, one-way analysis of variance (ANOVA) with Student-Newman-Keuls post-ANOVA tests were used to test for differences in variables between stent types. When either equal variance test or normality test failed, Kruskal-Wallis test (with Dunn's method for post-hoc group comparison) was conducted. A value of $p \leq 0.05$ was considered statistically significant. MedCalc Statistical Software version 14.12.0 (MedCalc Software bvba, Ostend, Belgium; http://www.medcalc.org; 2014) was used for the data analysis.

\section{RESULTS}

\section{Quantitative coronary angiography}

A summary of the QCA analysis is presented in Table 1. The vessels included in the study did not differ with regard to sizes as shown by similar RVDs between groups. The applied stent balloon inflation ensured comparable 120-125\% overstretch, 
Table 1. Baseline and 28-day follow-up vessel characteristics assessed by qualitative coronary angiography

\begin{tabular}{|c|c|c|c|c|}
\hline & frSES $(n=8)$ & ed-frSES $(n=7)$ & BMS $(n=4)$ & P (ANOVA) \\
\hline \multicolumn{5}{|l|}{ Baseline } \\
\hline $\mathrm{RVD}[\mathrm{mm}]$ & $2.54 \pm 0.4$ & $2.43 \pm 0.2$ & $2.86 \pm 0.4$ & 0.22 \\
\hline Balloon to artery ratio & $1.24 \pm 0.19$ & $1.27 \pm 0.1$ & $1.20 \pm 0.1$ & 0.82 \\
\hline Acute gain & $0.31 \pm 0.4$ & $0.32 \pm 0.17$ & 0.47 & 0.59 \\
\hline \multicolumn{5}{|l|}{28 days } \\
\hline In MLD [mm] & $2.05 \pm 0.4$ & $2.56 \pm 0.2^{*}$ & $2.36 \pm 0.6$ & 0.01 \\
\hline $\mathrm{RVD}[\mathrm{mm}]$ & $2.50 \pm 0.3$ & $2.74 \pm 0.2$ & $2.89 \pm 0.2$ & 0.06 \\
\hline$\% D S$ & $14.83(12.3-21.04)$ & $6.94 *(5.75-8.30)$ & $18.6(11.81-43.01)$ & 0.01 \\
\hline LLL [mm] & $0.80 \pm 0.5$ & $0.20 \pm 0.1^{*} \#$ & $0.96 \pm 0.5$ & 0.008 \\
\hline
\end{tabular}

${ }^{*} p<0.05$ for ed-SES vs. SES; \#p < 0.05 for edSES vs. BMS; BMS - bare metal stent; \%DS - percentage diameter stenosis; ed-frSES — elevated dose, fast-release sirolimus eluting stent; frSES — regular dose, fast-release sirolimus eluting stent; LLL — late lumen loss; MLD — minimal lumen diameter; RVD — reference vessel diameters; SES — sirolimus eluting stent

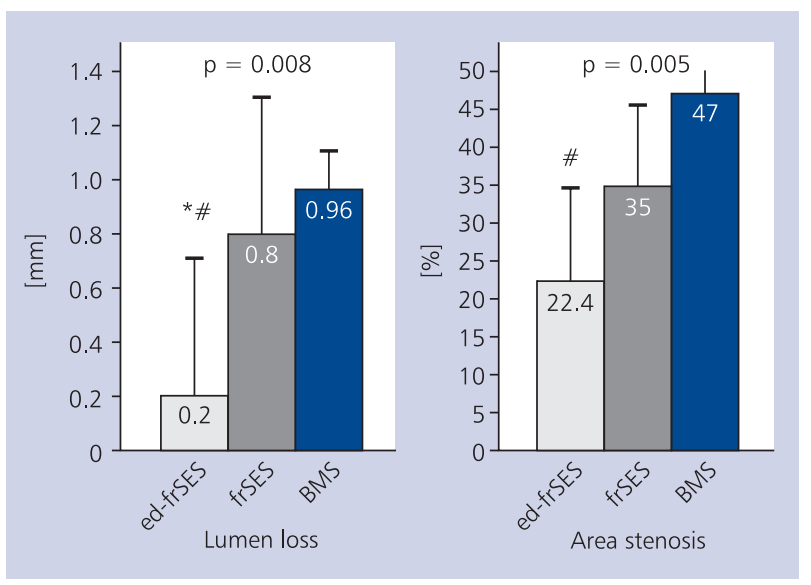

Figure 3. Angiographic and histomorphometric parameters representing device efficacy; BMS - bare metal stent; ed-frSES — elevated dose, fast-release sirolimus eluting stent; frSES regular dose, fast-release sirolimus eluting stent; * $p<0.05$ for ed-frSES vs. frSES; $\# p<0.05$ for ed-frSES vs. BMS

acute gain, and vessel diameters after procedure. The vessel flow was normal in all arteries and there were no dissections requiring additional stent implantation.

At 28 days the in-stent minimal lumen diameter in ed-frSES was higher by $20 \%$ when compared to SES $(p=0.007)$ and $10 \%$ when compared to BMS $(p=0.18)$. This corresponded with $\%$ DS, which in the ed-frSES was reduced by $53 \%$ and $64 \%$ when compared to frSES $(p=0.002)$ and BMS $(p=0.004)$, respectively. Finally, the late lumen loss was also reduced by $75 \%$ and $80 \%$ when compared to frSES ( $p=0.01$ ) and BMS subsequently ( $p=0.001$ ) (Fig. 3).

\section{Morphometric analysis}

A summary of the morphometric analysis is presented in Table 2. In the pathological, morphometric analysis the vessels sizes were comparable, as shown by similar external elastic lamina areas between groups. Additionally, stent areas were also similar. The neointimal area in the ed-frSES was reduced by nearly $60 \%(p=0.004)$ and $40 \%(p=0.082)$ when compared to BMS and frSES, consecutively. Correspondingly, the percentage area of stenosis was lowest in the ed-frSES, with a reduction of nearly $50 \%$ when compared to BMS ( $p=0.016)$ and $35 \%$ when compared with frSES ( $p=0.05)$. The area stenosis was also reduced by $27 \%$ in the frSES; however, it was not statistically significant (Fig. 3).

The healing and biocompatibility profile of all tested devices is presented in Figure 4. The injury, peri-strut, and adventitial inflammation were modest and comparable between groups. Endothelialisation score was statistically significantly, but marginally lower (by less than 3\%) in ed-frSES (ed-frSES: 2.93 vs. frSES:3. vs. BMS: $3, p=0.05$ ). Similarly, the fibrin deposition and lipid loading severity were low, but significantly higher in the ed-frSES. The representative stent cross sections are presented in Figure 5.

\section{DISCUSSION}

In the current study we evaluate the vascular response to different doses of fast releasing sirolimus and biodegradable polymer coated cobalt chromium stents in the porcine, coronary in-stent restenosis model. The elevated dose $\left(1.3 \mu \mathrm{g} / \mathrm{mm}^{2}\right)$ stent is compared with a regular dose $\left(1 \mu \mathrm{g} / \mathrm{mm}^{2}\right)$ reference stent, which both release $95 \%$ of the drug within three months from a biodegradable polymer platform in vivo [8]. Structurally identical BMS served as a control. The correctness of the methodology was shown by comparable vessel sizes and stents enrolled. Furthermore, the induced degrees of injuries as expressed by the balloon-to-artery ratios were similar between the groups. At one-month follow-up the angiographic measures of neointimal hyperplasia (late lumen loss and percentage diameter stenosis) were four- and five-fold lower when compared to regular dose, fast-release SES and BMS, consecutively $(p<0.01)$. In the histopathological analysis, the 
Table 2. Histopathological results of vessel morphometry, biocompatibility, and healing at 28 days of follow-up

\begin{tabular}{lcccc|} 
& fr-SES $(\mathbf{n}=\mathbf{8})$ & ed-frSES $(\mathbf{n}=\mathbf{7})$ & BMS $(\mathbf{n}=\mathbf{4})$ & P (ANOVA) \\
\hline EEL area $\left[\mathrm{mm}^{2}\right]$ & $10.67 \pm 1.8$ & $9.4 \pm 1.6$ & $13.25 \pm 2.7$ & 0.021 \\
Stent area $\left[\mathrm{mm}^{2}\right]$ & $7.7 \pm 1$ & $7.91 \pm 1.40$ & $9.36 \pm 1.9$ & 0.07 \\
Lumen area $\left[\mathrm{mm}^{2}\right]$ & $4.49 \pm 0.8$ & $6.1 \pm 1.7$ & $4.64 \pm 0.76$ & 0.069 \\
Neointimal area $\left[\mathrm{mm}^{2}\right]$ & $2.45 \pm 0.9^{*}$ & $1.65 \pm 0.7^{*}$ & $4.33 \pm 1.7$ & 0.003 \\
Area of stenosis $[\%]$ & $35 \pm 10.7 \%$ & $22.4 \pm 12.7 \% *$ & $47.5 \pm 12.5 \%$ & 0.005 \\
\hline
\end{tabular}

${ }^{*} p<0.05$ vs. BMS; BMS — bare metal stent; ed-frSES — elevated dose, fast-release sirolimus eluting stent; frSES — regular dose, fast-release sirolimus eluting stent; EEL — external elastic lamina

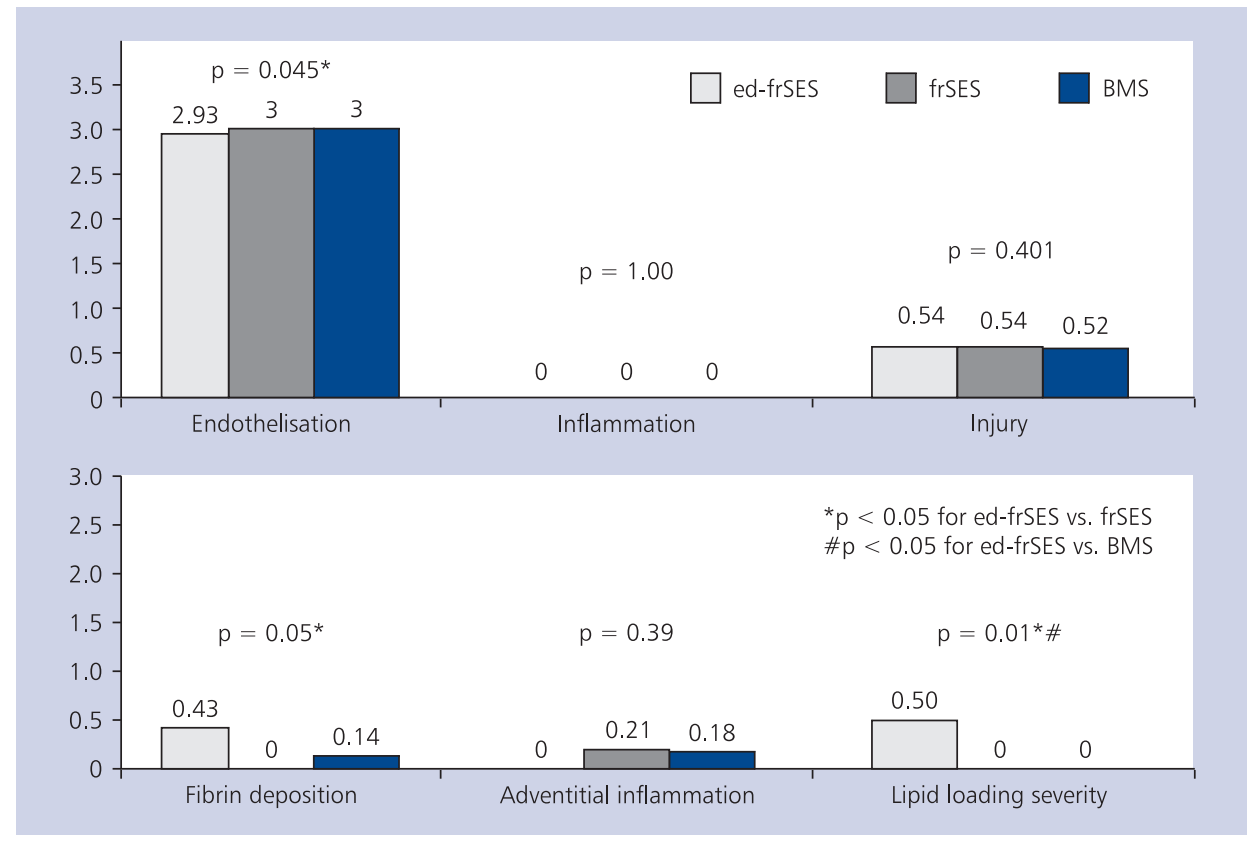

Figure 4. Qualitative histopathological analysis representing healing and biocompatibility; BMS — bare metal stent; ed-frSES — elevated dose, fast-release sirolimus eluting stent; frSES — regular dose, fast-release sirolimus eluting stent

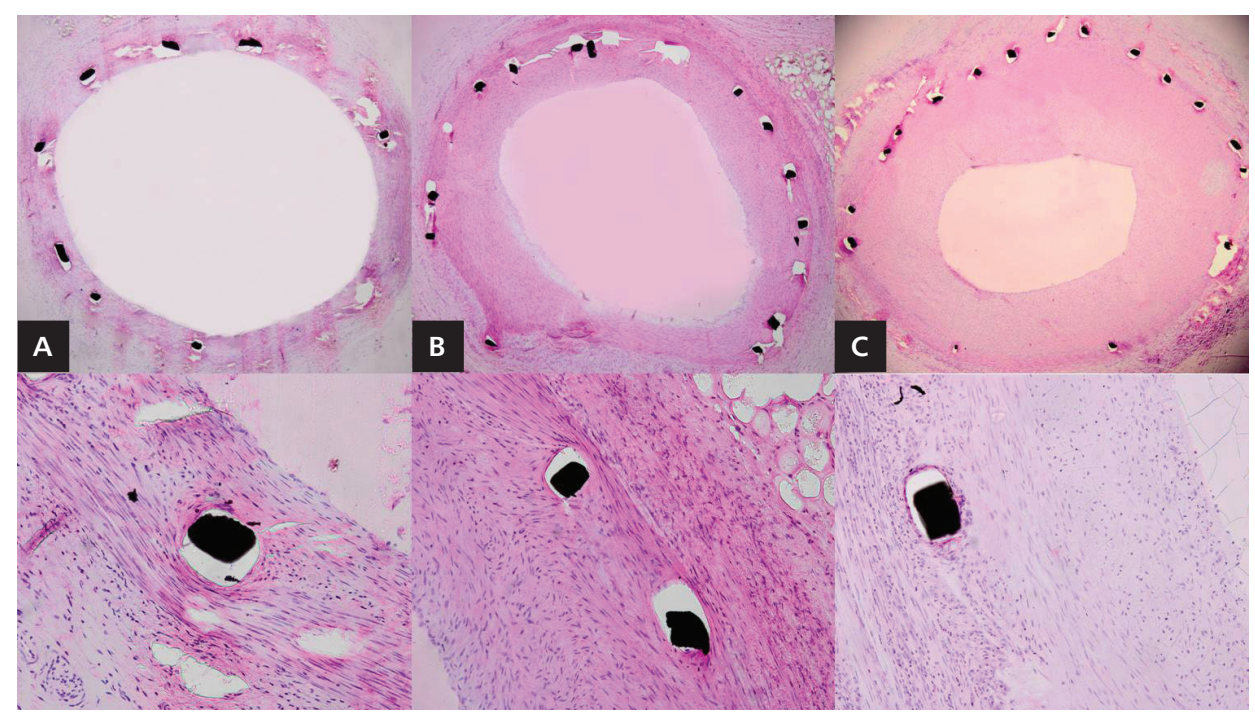

Figure 5. Representative histopathological stent-cross section; upper panel: stent-cross section (A. ed-frSES; B. frSES; C. BMS); lower panel: high power: peri-strut magnification 20x; abbreviations as in Figure 4 
reduction of late lumen loss was confirmed by significantly lower percentage area stenosis and neointimal area in the ed-frSES when compared to regular dose frSES and BMS. No efficacy signal in the angiographic analysis was reported between regular dose SES and BMS; however, in histological analysis the measures of neointimal hyperplasia tended to fall between the ed-frSES and BMS, reporting a clear dose dependent effect. Interestingly, despite higher dose of eluted sirolimus, healing expressed as endothelialisation, fibrin deposition, although numerically in favour of regular dose frSES and BMS, seems to be very satisfactory. Slightly decreased endothelialisation score and signs of fibrin deposition in the ed-frSES are well-described signatures of vascular response to the sirolimus [2] and also support the notion of dose effect.

The optimisation of vascular response and clinical outcome of DES technologies is dependent upon multiple factors. The utilisation of biodegradable and biocompatible polymers has shown theoretical advantages in vitro and in the experimental setting [12]; however, the clinical benefit, especially when compared with second-generation durable polymer counterparts, is inconclusive [13). It seems that the type of drug, and specifically modification of the release profile, plays more pronounced role. Fast-release ZES (Endeavour, Medtronic) has shown a significant difference in clinical performance against paclitaxel-eluting stents (PES), as shown by significant risk reduction in late and very late stent thrombosis, cardiac death, and myocardial infarction [14, 15]. On the other hand, at longer follow-up the excellent safety profile did not translate into efficacy, with inferior rates of angiographic surrogates of restenosis and target vessel failure when compared to SES and PES [15-17]. Following these results, fast-release ZES were replaced by slow-release counterparts yielding improved neointimal inhibition [7] and non-inferior clinical outcomes when compared to everolimus eluting stents [18].

Therefore, in the current study, to the best of our knowledge for the first time, we evaluate the biological effect of an elevated dose of sirolimus deployed on a fast-release biodegradable-polymer stent matrix. This concept was chosen to combine the preferable safety of fast sirolimus release kinetics and the efficacy of long-term tissue retention. Previously, a similar effect and reduction of delayed healing was observed by lowering the sirolimus dose from the hydroxyapatite, slow-release matrix [19]. Also, a positive vascular effect has been accomplished in the Endeavor Resolute stent, by polymer design modification, and as a consequence the release kinetics. Slow-release ZES has demonstrated less late lumen loss but similar biocompatibility to BMS and fast-release ZES [20-22]. In our approach the vascular effect (restenosis inhibition) was achieved with a sirolimus dose elevation of $30 \%$, which is contrary to previous reports in which mathematical modelling predicted that an increase in sirolimus dose and elution would not affect the sirolimus receptor binding capabilities, and as a consequence the biological effect [23].
In our study, a clear dose-dependent neointimal inhibition effect was reported. This result contrary to the previously-cited study might be explained by the analytical rather than empirical methodology and multifactorial mechanism of action of sirolimus [24].

The safety and efficacy of a studied fr-edSES (Alex, Balton) was shown in the first-in-man study [25], in which temporal vascular healing was evaluated with serial Optical Coherence Tomography (OCT) evaluation. The favourable healing profile was confirmed at three months, at which time $97 \%$ of struts were covered by neointima. The efficacy was sustained until 12 months with in-stent late-lumen loss of $0.14 \mathrm{~mm}$. Longer follow-up in the clinical setting is required to establish a full safety profile of the studied stent.

\section{Limitations of the study}

The limitations of this study include the nature of the experimental preclinical model as a human clinical surrogate and utilisation of a healthy domestic swine, without underlying disease. Furthermore, no intravascular imaging was utilised to prevent injury to endothelium caused by mechanical pullback to provide unbiased histopathological results. Histopathological evaluation was performed with H\&E staining only.

\section{CONCLUSIONS}

In conclusion, the dose-dependent vascular effect of sirolimus, rapidly eluted from the biodegradable polymer and stent matrix, was observed. The ed-frSES provided efficacious neointimal hyperplasia inhibition when compared to regular dose frSES; however, the healing was satisfactory. These findings support the notion that not only drug release kinetics, but also the dose of the eluted drug influences the biological response.

The clinical implications are important. The combination of fast release kinetics and dose-efficient sirolimus delivery from the stent and biodegradable platform contributes to early strut coverage and healing, as shown in the first-in-man OCT study. In future this may significantly shorten the duration of double antiplatelet therapy.

\section{Acknowledgements}

This study was supported by unrestricted research grant from Balton Company, Warsaw, Poland.

Conflict of interest: Piotr P. Buszman - unrestricted research grants, Balton, Warsaw, Poland; Krzysztof Milewski - unrestricted research grants and consultancy, Balton, Warsaw, Poland.

\section{References}

1. Camenzind E, Steg PG, Wijns W. Stent thrombosis late after implantation of first-generation drug-eluting stents: a cause for concern. Circulation, 2007; 115: 1440-1455.

2. Nakazawa G, Finn AV, John MC et al. The significance of preclinical evaluation of sirolimus-, paclitaxel-, and zotarolimus-eluting stents. Am J Cardiol, 2007; 100: 36M-44M.

3. Stone GW, Midei M, Newman W et al. Comparison of an everolimus-eluting stent and a paclitaxel-eluting stent in patients with 
coronary artery disease: a randomized trial. JAMA, 2008; 299: 1903-1913. doi: 10.1001/jama.299.16.1903.

4. Windecker S, Serruys PW, Wandel S et al. Biolimus-eluting stent with biodegradable polymer versus sirolimus-eluting stent with durable polymer for coronary revascularisation (LEADERS): a randomised non-inferiority trial. Lancet, 2008; 372: 1163-1173. doi: 10.1016/S0140-6736(08)61244-1.

5. Stefanini GG, Byrne RA, Serruys PW et al. Biodegradable polymer drug-eluting stents reduce the risk of stent thrombosis at 4 years in patients undergoing percutaneous coronary intervention: a pooled analysis of individual patient data from the ISAR-TEST 3, ISAR-TEST 4, and LEADERS randomized trials. Eur Heart J, 2012; 33: 1214-1222. doi: 10.1093/eurheartj/ehs086.

6. Stefanini GG, Kalesan B, Serruys PW et al. Long-term clinical outcomes of biodegradable polymer biolimus-eluting stents versus durable polymer sirolimus-eluting stents in patients with coronary artery disease (LEADERS): 4 year follow-up of a randomised non-inferiority trial. Lancet, 2011; 378: 1940-1948. doi: 10.1016/S0140-6736(11)61672-3.

7. Guagliumi G, Ikejima H, Sirbu V et al. Impact of drug release kinetics on vascular response to different zotarolimus-eluting stents implanted in patients with long coronary stenoses: the LongOCT study (Optical Coherence Tomography in Long Lesions). J Am Coll Cardiol Cardiovasc Interv, 2011; 4: 778-785. doi: 10.1016/j.jcin.2011.04.007.

8. Orlik B, Buszman PP, Jelonek M et al. TCT-813 A novel method for evaluation of polymer absorption from sirolimus eluting stent and its influence on biological effects. J Am Coll Cardiol, 2013; 62: B246.

9. Institute of Laboratory Animal Resources NRC. Principles of Care of Laboratory Animals. NIH Publication 1996; No. 85-23.

10. Schwartz RS, Huber KC, Murphy JG et al. Restenosis and the proportional neointimal response to coronary artery injury: results in a porcine model. J Am Coll Cardiol, 1992; 19: 267-274.

11. Kornowski R, Hong MK, Tio FO et al. In-stent restenosis: contributions of inflammatory responses and arterial injury to neointimal hyperplasia. J Am Coll Cardiol, 1998; 31: 224-230.

12. Eppihimer MJ, Sushkova N, Grimsby JL et al. Impact of stent surface on thrombogenicity and vascular healing: a comparative analysis of metallic and polymeric surfaces. Circ Cardiovasc Interv, 2013; 6: 370-377. doi: 10.1161/CIRCINTERVENTIONS.113.000120.

13. Palmerini T, Biondi-Zoccai G, Della Riva D et al. Clinical outcomes with bioabsorbable polymer- versus durable polymer-based drug-eluting and bare-metal stents: evidence from a comprehensive network meta-analysis. J Am Coll Cardiol, 2014; 63: 299-307. doi: 10.1016/j.jacc.2013.09.061.

14. Kirtane AJ, Leon MB, Ball MW et al. The "final" 5-year follow-up from the ENDEAVOR IV trial comparing a zotarolimus-eluting stent with a paclitaxel-eluting stent. JACC Cardiovasc Interv, 2013; 6: 325-333. doi: 10.1016/j.jcin.2012.12.123.

15. Leon MB, Mauri L, Popma JJ et al. A randomized comparison of the Endeavor zotarolimus-eluting stent versus the TAXUS paclitaxel-eluting stent in de novo native coronary lesions 12-month outcomes from the ENDEAVOR IV trial. J Am Coll Cardiol, 2010; 55: 543-554. doi: 10.1016/j.jacc.2009.08.067.

16. Kandzari DE, Leon MB, Popma JJ et al. Comparison of zotarolimus-eluting and sirolimus-eluting stents in patients with native coronary artery disease: a randomized controlled trial. J Am Coll Cardiol, 2006; 48: 2440-2447.

17. Garg S, Serruys PW. Coronary stents: current status. J Am Coll Cardiol, 2010; 56 (10 suppl.): S1-S42. doi: 10.1016/j.jacc.2010.06.007.

18. Serruys PW, Silber S, Garg S et al. Comparison of zotarolimus-eluting and everolimus-eluting coronary stents. NEngl J Med, 2010; 363: 136-146. doi: 10.1056/NEJMoa1004130.

19. van der Giessen WJ, Sorop O, Serruys PW et al. Lowering the dose of sirolimus, released from a nonpolymeric hydroxyapatite coated coronary stent, reduces signs of delayed healing. J Am Coll Cardiol Cardiovasc Interv, 2009; 2: 284-290. doi: 10.1016/j. jcin.2008.12.012.

20. Udipi K, Chen M, Cheng P et al. Development of a novel biocompatible polymer system for extended drug release in a next-generation drug-eluting stent. J Biomed Mater Res A, 2008; 85: 1064-1071.

21. Resolute Integrity Zotarolimus-Eluting Coronary Stent System. Summary of Safety and Effectiveness Data. 2011.

22. Udipi K, Melder RJ, Chen M et al. The next generation Endeavor Resolute Stent: role of the BioLinx Polymer System. EuroIntervention, 2007; 3: 137-139.

23. Tzafriri AR, Groothuis A, Price GS, Edelman ER. Stent elution rate determines drug deposition and receptor-mediated effects. J Control Release, 2012; 161: 918-926. doi: 10.1016/j. jconrel.2012.05.039.

24. Costa MA, Simon DI. Molecular basis of restenosis and drug-eluting stents. Circulation, 2005; 111: 2257-2273.

25. Legutko JG, Robert J, Buszman PE. TCT-565 OCT evaluation of the time course of vessel healing following implantation of new generation biodegradable polymer-coated and sirolimus-eluting cobalt-chromium coronary stent system (ALEX OCT Study). J Am Coll Cardiol, 2013; 62: B170-B171.

Cite this article as: Buszman PP, Orlik B, Pająk J et al. Dose-dependent vascular response following delivery of sirolimus via fast releasing, biodegradable polymer stent matrix: an experimental study in the porcine coronary model of restenosis. Kardiol Pol, 2015; 73: 916-923. doi: 10.5603/KP.a2015.0085. 


\section{Zależna od dawki odpowiedź ściany naczyniowej na implantację stentu szyblko uwalniającego lek, pokrytego polimerem biodegradowalnym ze zwiększoną dawką sirolimusa: badanie eksperymentalne na modelu restenozy tętnic wieńcowych świni domowej}

Piotr P. Buszman ${ }^{1}$, Bartłomiej Orlik¹, Jacek Pająk², Michał Jelonek ${ }^{1}$, Agata Krauze ${ }^{1}$, Adam Janas ${ }^{1}$, Jacek Legutko ${ }^{3}$, Wojciech Wojakowski ${ }^{2}$, Paweł E. Buszman ${ }^{1}$, Krzysztof Milewski $^{1}$

${ }^{1}$ Centrum Badawczo-Rozwojowe American Heart of Poland SA, Katowice

2Śląski Uniwersytet Medyczny, Katowice

3Zakład Hemodynamiki i Angiokardiografii, Collegium Medicum, Uniwersytet Jagielloński, Szpital Uniwersytecki, Kraków

\section{Streszczenie}

Wstęp: Chociaż stenty powlekane analogami rapamycyny o szybkim profilu uwalniania leku udowodniły swoje bezpieczeństwo, to ich skuteczność w zapobieganiu restenozie jest niewystarczająca.

Cel: Celem pracy była ocena efektów tkankowych w odpowiedzi na implantację stentu szybko uwalniającego lek, pokrytego polimerem biodegradowalnym ze zwiększoną dawką sirolimusa (ed-frSES, Alex, Balton) z wykorzystaniem modelu restenozy tętnic wieńcowych świni domowej.

Metody: Wszczepiono 19 stentów ze 120\% przerozmiarowaniem (tzw. overstretch) do tętnic wieńcowych 7 świń domowych: 7 stentów typu ed-frSES z $1,3 \mu \mathrm{g} / \mathrm{mm}^{2}$ sirolimusa, 8 stentów szybko uwalniających lek ze standardową dawką sirulimusa (frSES) i 8 stentów metalowych (BMS). Po 28 dniach obserwacji wykonano angiografię z oceną ilościową. Następnie zwierzęta zostały poddane eutanazji, a badane segmenty wypreparowane w celu przeprowadzenia analizy histopatologicznej.

Wyniki: Po 28 dniach późna utrata światła w ocenie angiograficznej była najniższa w grupie ze zwiększoną dawką sirolimusa (ed-frSES: $0,20 \pm 0,2$ vs. frSES: $0,80 \pm 0,5$ vs. BMS: $0,96 \pm 0,5 \mathrm{~mm} ; p<0,01$ ). Podobne wyniki uzyskano $w$ analizie histopatologicznej, w której obserwowano istotnie mniejsze procentowe zwężenie pola przekroju w grupie ed-frSES (ed-frSES: $22,4 \pm 12,7 \%$ vs. frSES: $35 \pm 10,7 \%$ vs. BMS: $47,5 \pm 12,5 \%$; $p<0,01$. W żadnej z badanych grup nie zaobserwowano okołoprzesłowego nacieku zapalnego. Poziom endotelializacji był nieco mniejszy w grupie ed-frSES, jednak różnica ta nie była istotna statystycznie (ed-frSES: 2,93 vs. frSES: 3 . vs. BMS: $3 ; p=0,05$ ). Ponadto $w$ grupie ed-frSES zaobserwowano okołoprzesłowo nieznaczną ilość włóknika (ed-frSES: 0,4 vs. frSES: 0 vs. BMS: $0 ; p=0,05$ ).

Wnioski: Potwierdzono zależną od dawki sirolimusa odpowiedź tkankową. Stenty szybko uwalniające lek ze zwiększoną dawką sirolimusa (ed-frSES) umożliwiają zadowalające gojenie się ściany naczyniowej, podobne do stentów ze standardową dawką leku, przy jednocześnie skuteczniejszym hamowaniu restenozy.

Słowa kluczowe: stenty uwalniające sirolimus, szybkie uwalnianie, polimer biodegradowalny, model tętnic wieńcowych świni

Kardiol Pol 2015; 73, 10: 916-923 